\title{
Purification of HCV-remodeled and Control ER Membranes
}

David Paul ${ }^{\star}$ and Ralf Bartenschlager ${ }^{*}$

Department of Infectious Diseases, Molecular Virology, University of Heidelberg, Heidelberg, Germany

*For correspondence: david paul@med.uni-heidelberg.de; ralf bartenschlager@med.uniheidelberg.de

[Abstract] As for all positive strand RNA viruses, hepatitis C virus (HCV) RNA replication is tightly associated with rearranged host cell membranes, termed viral replication factories. However, up to now little is known about both viral and cellular constituents of viral replication factories. Here, we describe a protocol to specifically isolate HCV-remodeled host cell membranes and endoplasmic reticulum (ER) membranes of naïve cells, by using a functional NS4B HA-tagged subgenomic replicon and a C-terminally HA-tagged calnexin-overexpressing cell line, respectively. Post-nuclear whole cell membrane fractions are first enriched by density gradient centrifugation, followed by HA-specific affinity tag purification. Upon elution under native conditions, purified samples can be subject to a variety of biochemical and functional assays.

\section{Materials and Reagents}

1. Huh7 human hepatoma cells, stably replicating a wt JFH1 subgenomic replicon (NS4B ${ }^{w t}$ ) and a recombinant replicon cell line harboring the HA epitope and the adaptive mutation Q31R in NS4B (NS4B ${ }^{\mathrm{HA}}$ ) (Paul et al., 2013) and Huh7 hepatoma cells stably overexpressing C-terminally HA-tagged calnexin (CANX ${ }^{\mathrm{HA}}$ ) (Paul et al., 2013)

2. $100 \mathrm{U} / \mathrm{ml}$ Pencillin and Streptomycin (Life Technologies, Gibco ${ }^{\circledR}$, catalog number: 15140122)

3. $10 \%(v / v)$ Fetal Calf Serum (Life Technologies, Gibco ${ }^{\circledR}$, catalog number: 10270-106)

4. 1x nonessential amino acids (Life Technologies, catalog number: 11140-035)

5. Geneticin (Life Technologies, Gibco ${ }^{\circledR}$, catalog number: 11811-098)

6. Blasticidin (Life Technologies, Gibco ${ }^{\circledR}$, catalog number: R210-01)

7. Bradford reagent

8. $\mathrm{NaN}_{3}$ (Sigma-Aldrich, catalog number: S2002)

9. Hemagglutinin peptide (Sigma-Aldrich, catalog number: 12149)

10. Anti-HA agarose beads (Sigma-Aldrich, catalog number: A2095)

11. 1x protease inhibitor cocktail (Roche Diagnostics, catalog number: 04693116001) 
12. Dulbecco's Modified Eagle's Medium (DMEM) (Life Technologies, Gibco ${ }^{\circledR}$, catalog number: 41965-039) (see Recipes)

13. Bovine serum albumin (BSA) standard (see Recipes)

14. PBS (sterile) (see Recipes)

15. Hypotonic buffer (see Recipes)

16. Sucrose (see Recipes)

17. $5 \mathrm{M} \mathrm{NaCl}$ solution (see Recipes)

18. IP washing buffer I (see Recipes)

19. IP washing buffer II (see Recipes)

20. IP elution buffer (see Recipes)

\section{Equipment}

1. $15 \mathrm{~cm}$ cell culture dishes

2. $37^{\circ} \mathrm{C}, 5 \% \mathrm{CO}_{2}$ cell culture incubator

3. Cell scraper (e.g. SARSTEDT AG, catalog number: 83.1830)

4. Dounce homogenizer (1 ml) (e.g. WHEATON, catalog number: 357538)

5. Table top cooling centrifuge with swinging buckets for $15 \mathrm{ml}$ and $50 \mathrm{ml}$ falcon tubes (e.g. Heraeus Multifuge 3-SR)

6. Open top polyclear ultracentrifuge tubes for SW40 rotor (Seton Identification Products, catalog number: 7031)

7. Ultracentrifuge and SW40 rotor and buckets (e.g. Beckman Optima LE80K Ultracentrifuge and Beckman SW40Ti rotor and buckets)

8. Lab stand and clamp

9. $19 \mathrm{G}$ needle (e.g. BD, catalog number: 301500 )

10. Spectrophotometer (e.g. Amersham Ultrospec 2100 pro) and cuvettes (e.g. SARSTEDT AG, catalog number: 67.742)

11. Rotator wheel for Eppendorf tubes (e.g. Labinco, model: L28, catalog number: 2800)

12. Table top cooling centrifuge for Eppendorf reaction tubes (e.g. Eppendorf, model: 5417R)

13. Eppendorf Thermomixer compact

\section{Procedure}

1. Cells are grown in $\mathrm{DMEM}_{\text {cplt }}$ in the incubator in a $5 \% \mathrm{CO}_{2}$ environment at $37{ }^{\circ} \mathrm{C}$, in presence of $0.5 \mathrm{mg} / \mathrm{ml}$ geneticin in case of replicon cell lines and $10 \mu \mathrm{g} / \mathrm{ml}$ blasticidin for CANX ${ }^{H A}$ overexpressing cells. Around $5-7.5 \times 10^{7}$ cells are needed for the experiment, which equals six $15 \mathrm{~cm}$ cell culture dishes. 
Note: Cell confluence should not exceed $90 \%$ at the day of harvest.

2. Cells are washed twice in PBS and subsequently scraped in $5 \mathrm{ml}$ PBS per dish and transferred into a $50 \mathrm{ml}$ falcon tube.

3. The cells are pelleted at $700 \times g$ for $10 \mathrm{~min}$ at $4{ }^{\circ} \mathrm{C}$.

4. The supernatant is removed and cells are resuspended in $2 \mathrm{ml}$ hypotonic buffer containing $1 x$ protease inhibitor cocktail.

5. Cells are incubated on ice for $30 \mathrm{~min}$.

6. Cells are broken by 40 strokes with the dounce homogenizer.

Note: Turn pestle on the bottom of mortar chamber by $90^{\circ}$ during each stroke.

7. Cell debris and nuclei are pelleted by centrifugation at $700 \times \mathrm{g}$ for $10 \mathrm{~min}$ at $4{ }^{\circ} \mathrm{C}$.

8. Preparation of discontinuous sucrose gradient in ultra-centrifugation SW40 tubes:

Pipette $4 \mathrm{ml} 70 \%$ sucrose on the bottom and consecutively overlay carefully with $3 \mathrm{ml}$ $60 \%$ sucrose, $2 \mathrm{ml} 40 \%$ sucrose and $2 \mathrm{ml} \mathrm{30 \%} \mathrm{sucrose.}$

9. $2 \mathrm{ml}$ post-nuclear supernatants (see step 7) are carefully layered on top of the sucrose gradient.

10. Membrane fractions are separated in the sucrose gradient by ultra-centrifugation for $4 \mathrm{~h}$ at 130,000

$x g$ using a SW40 rotor.

11. Place tubes in the clamp of a lab stand, and carefully make a hole at the bottom using a $19 \mathrm{G}$ needle. Collect $131 \mathrm{ml}$ fractions, with fraction number 1 being the lowest one and number 13 representing the top of the gradient.

Note: The elution speed of the gradient should be around 1 drop per second, which can be adjusted by the hole size on the bottom.

12. Gradient fractions can be analyzed for their protein and HCV RNA content. Typically the majority of HCV RNA and proteins are found in fractions 7-11 (Paul et al., 2013), which thus are subsequently pooled.

13. Equilibrate pooled fractions $7-11$ to $150 \mathrm{mM} \mathrm{NaCl}$ by adding an appropriate volume of 5 $\mathrm{M} \mathrm{NaCl}$ solution (e.g. $150 \mu \mathrm{l} 5 \mathrm{M} \mathrm{NaCl}$ for $5 \mathrm{ml}$ fractions 7-11), and store a small aliquot ( $\sim 50 \mu$ as input samples).

14. Determine protein concentration in pooled fractions by using the Bradford assay and a BSA standard curve.

15. Wash $25 \mu \mathrm{l}$ anti-HA agarose beads with $500 \mu \mathrm{l}$ IP washing buffer I in $2 \mathrm{ml}$ Eppendorf tubes (for each NS4B ${ }^{w t}$, NS4B ${ }^{H A}$ and CANX ${ }^{H A}$ ). Pellet beads by centrifugation at $3,800 x$ $g$ for 3 min at $4{ }^{\circ} \mathrm{C}$ and remove supernatant.

16. Incubate beads with membrane fraction containing a total of around $1 \mathrm{mg}$ protein (approximately 1-1.5 ml) for $4 \mathrm{~h}$ on a rotator wheel at $4{ }^{\circ} \mathrm{C}$.

Note: The total protein input should be the same for the three IP samples. 
17. Pellet beads and bound material by centrifugation at $3,800 \times g$ for 3 min at $4{ }^{\circ} \mathrm{C}$ and remove supernatant.

18. Wash beads three times with $1 \mathrm{ml} I \mathrm{P}$ washing buffer I and in between each washing step pellet beads as described in step 17.

19. Add $1 \mathrm{ml}$ of IP washing buffer I and transfer beads and bound material into a new eppendorf tube and pellet beads as described in step 17.

20. Wash beads with $1 \mathrm{ml}$ IP washing buffer II and pellet beads as described in step 17.

21. Elution of bound material:

a. Add $100 \mu \mathrm{l}$ IP elution buffer to the beads and shake the samples for 15 min at 1,100 rpm at $25^{\circ} \mathrm{C}$.

b. Pellet beads by centrifugation at $3,800 \times g$ for $3 \mathrm{~min}$ at $25^{\circ} \mathrm{C}$.

c. Collect and keep supernatant.

d. Add $100 \mu \mathrm{IIP}$ elution buffer to the beads and shake the samples for $15 \mathrm{~min}$ at 1,100 rpm at $25^{\circ} \mathrm{C}$.

e. Pellet beads by centrifugation at $3,800 \times g$ for $3 \mathrm{~min}$ at $25^{\circ} \mathrm{C}$.

f. Collect and pool with supernatant from step 21c.

22. IP elution fractions can be analyzed in a variety of subsequent assays, including western blot, RNA quantification as well as electron microscopy analyses (Paul et al., 2013).

\section{$\underline{\text { Recipes }}$}

1. Complete Dulbecco's Modified Eagle's Medium (DMEMcplt)

2 mM L-glutamine

$1 x$ nonessential amino acids

Supplemented with $100 \mathrm{U} / \mathrm{ml}$ Pencillin and Streptomycin

$10 \%(\mathrm{v} / \mathrm{v})$ Fetal Calf Serum (heat inactivated at $56^{\circ} \mathrm{C}$ for $30 \mathrm{~min}$ )

2. BSA standard

Dissolve $0.1 \mathrm{~g}$ of BSA in $10 \mathrm{ml} \mathrm{IP}$ washing buffer I (final concentration $10 \mu \mathrm{g} / \mu \mathrm{l}$ )

Use 1, 2, 3 and $4 \mu$ for the BSA standard in the Bradford assay

3. PBS

$8 \mathrm{mM} \mathrm{Na}_{2} \mathrm{HPO}_{4}$

$2 \mathrm{mM} \mathrm{NaH}_{2} \mathrm{PO}_{4}$

$140 \mathrm{mM} \mathrm{NaCl}$

$0.27 \mathrm{mM} \mathrm{KCl}$

$0.176 \mathrm{mM} \mathrm{KH}_{2} \mathrm{PO}_{4}$

4. Hypotonic buffer

$10 \mathrm{mM}$ Tris $(\mathrm{pH} 8)$ 
$1.5 \mathrm{mM} \mathrm{MgCl}_{2}$

$10 \mathrm{mM} \mathrm{NaAc}$

5. Sucrose

$70 \%$ dissolve $70 \mathrm{~g}$ sucrose in $100 \mathrm{ml}$ hypotonic buffer

$60 \%$ dissolve $60 \mathrm{~g}$ sucrose in $100 \mathrm{ml}$ hypotonic buffer

$40 \%$ dissolve $40 \mathrm{~g}$ sucrose in $100 \mathrm{ml}$ hypotonic buffer

$30 \%$ dissolve $30 \mathrm{~g}$ sucrose in $100 \mathrm{ml}$ hypotonic buffer

6. $5 \mathrm{M} \mathrm{NaCl}$ solution

Dissolve $1,461 \mathrm{~g} \mathrm{NaCl}$ in $500 \mathrm{ml}$ water

7. IP washing buffer I

Hypotonic buffer containing 40\% Sucrose and $150 \mathrm{mM} \mathrm{NaCl}$

8. IP washing buffer II

Hypotonic buffer containing 10\% Sucrose and $150 \mathrm{mM} \mathrm{NaCl}$

9. IP elution buffer

IP washing buffer II containing $250 \mu \mathrm{g} / \mathrm{ml}$ hemagglutinin peptide and $0.01 \% \mathrm{NaN}_{3}$

\section{Acknowledgments}

The protocol described here has been published originally in a short form in Paul et al. (2013). Research was supported by the DFG TRR83 TP13.

\section{References}

1. Paul, D., Hoppe, S., Saher, G., Krijnse-Locker, J. and Bartenschlager, R. (2013). Morphological and biochemical characterization of the membranous hepatitis $\mathrm{C}$ virus replication compartment. J Virol 87(19): 10612-10627. 